\title{
Alliinase from Ensifer adhaerens and Its Use for Generation of Fungicidal Activity
}

\author{
Masahiro Yutani', Hiroko Taniguchi', Hasibagan Borjihan', Akira Ogita ${ }^{1,2}$, Ken-ichi Fujita', Toshio Tanaka ${ }^{1 *}$
}

\begin{abstract}
A bacterium Ensifer adhaerens FERM P-19486 with the ability of alliinase production was isolated from a soil sample. The enzyme was purified for characterization of its general properties and evaluation of its application in on-site production of allicin-dependent fungicidal activity. The bacterial alliinase was purified 300-fold from a cell-free extract, giving rise to a homogenous protein band on polyacrylamide gel electrophoresis. The bacterial alliinase $(96 \mathrm{kDa})$ consisted of two identical subunits $(48 \mathrm{kDa})$, and was most active at $60^{\circ} \mathrm{C}$ and at $\mathrm{pH}$ 8.0. The enzyme stoichiometrically converted (-)-alliin ((-)-S-allyl-L-cysteine sulfoxide) to form allicin, pyruvic acid, and ammonia more selectively than (+)-alliin, a naturally occurring substrate for plant alliinase ever known. The C-S lyase activity was also detected with this bacterial enzyme when S-alkyl-L-cysteine was used as a substrate, though such a lyase activity is absolutely absent in alliinase of plant origin. The enzyme generated a fungicidal activity against Saccharomyces cerevisiae in a time- and a dose-dependent fashion using alliin as a stable precursor. Alliinase of Ensifer adhaerens FERM P-19486 is the enzyme with a novel type of substrate specificity, and thus considered to be beneficial when used in combination with garlic enzyme with respect to absolute conversion of ( \pm )-alliin to allicin.
\end{abstract}

\section{Introduction}

Allicin (diallyl thiosulfinate, Figure 1a) is the best-known active compound of freshly crushed garlic extract, and is known to possess a vast variety of biological effects: antimicrobial, anti-inflammatory, antithrombotic, anticancer, and antiatherosclerotic activities (Stoll and Seeback 1951; Block 1985; Tsai et al. 1985; Agarwal 1996; Ankri and Mirelman 1999; Siegel et al. 1999). This allyl-sulfur compound is synthesized as a result of condensation of allyl sulfenate, which is produced depending on the $\mathrm{C}-\mathrm{S}$ lyase activity of alliinase (EC 4.4.1.4) on (+)-alliin ((+)-S-allyl-L-cysteine sulfoxide), a naturally occurring diastereomer, as illustrated in Figure 1a (Siegel et al. 1999; Jones et al. 2004). Alliinase is therefore distinguished from $S$-alkyl-L-cysteine lyase (EC 4.4.1.6), which simply exhibits C-S lyase activity as to produce alkyl mercaptan in addition to pryruvic acid and ammonia (Figure 1b). Alliinase has been purified from garlic, onion, and other plants of the genus Allium (Schwimmer and Mazelis 1963; Mazelis and Crews

\footnotetext{
* Correspondence: tanakato@sci.osaka-cu.ac.jp

${ }^{1}$ Department of Biology and Geosciences, Graduate School of Science, Osaka City University, 3-3-138 Sugimoto, Sumiyoshi-ku, Osaka 558-8585, Japan. Full list of author information is available at the end of the article
}

1968; Tobkin and Mazelis 1979; Nock and Mazelis 1986; Landshuter et al. 1994; Lohmüller et al. 1994; Rabinkov et al. 1994; Manabe et al. 1998). The enzymatic production of allicin is thought to occur in nature as a result of injury of the plant tissue that enables interaction of the enzyme in vacuoles with alliin accumulated in the cytosol (Lancaster and Collin 1981). Therefore, allicin production has been discussed as a defense mechanism of the plant against microbial infection or insect attack (Slusarenko et al. 2008).

On-site production of allicin from a stable precursor alliin is attractive if this can be applied for various clinical purposes. In fact, with increasing interest in the efficacy of allicin in the purposes, its production has been devised both in vitro and in vivo with the aid of garlic alliinase (Miron et al. 2003; Shadkchan et al. 2004; Fry et al. 2005). Alliinase from microbial origin is another choice for this purpose. Murakami (1960) first reported the occurrence of alliinase in microbial world based on the detection of the corresponding enzyme activity in acetone-powdered cell-free extract from Bacillus subtilis. Durbin and Uchytil (1971) then reported the production of the enzyme by Penicillium corymbiferum. The partially purified enzyme

\section{SpringerOpen ${ }^{\circ}$}

(C) 2011 Yutani et al; licensee Springer. This is an Open Access article distributed under the terms of the Creative Commons Attribution License (http://creativecommons.org/licenses/by/2.0), which permits unrestricted use, distribution, and reproduction in any medium, provided the original work is properly cited. 


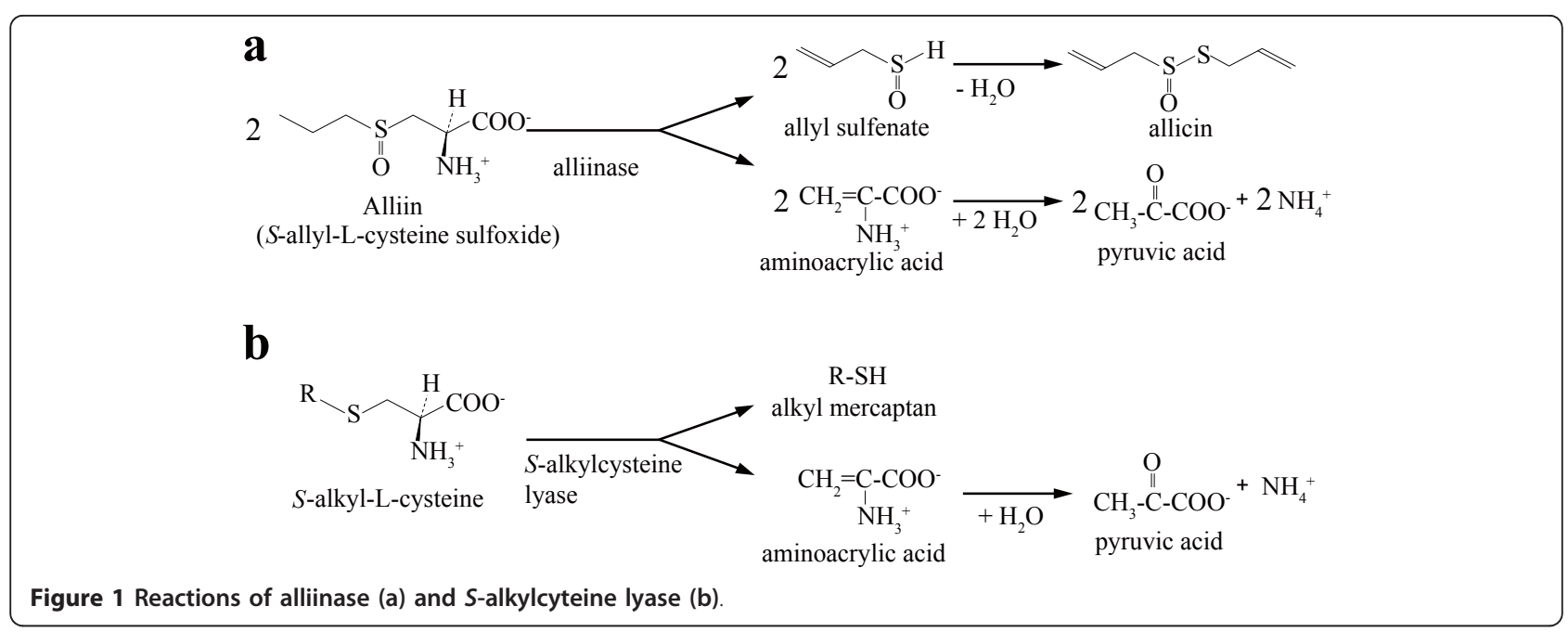

stoichiometrically converted alliin to pyruvic acid, ammonia, and allicin, showing none of lyase activity on $S$-alkyl-L-cysteine. In the present study, we isolated a microorganism, which generates allicin-like odor during the growth in medium containing $( \pm)$-alliin, and purified the enzyme involved in the metabolic conversion of this amino acid derivative into an odorous compound. We hereby report isolation of an alliinaseproducing bacterium, purification of the bacterial enzyme, and its substrate specificity characterized by the selectivity toward (-)-alliin. We also evaluate a combination of the enzyme and alliin with respect to on-site generation of allicin-dependent fungicidal activity using the yeast Saccharomyces cerevisiae as a model of fungal cells.

\section{Materials and methods}

Isolation of alliinase-producing microorganism

Appropriately diluted suspension of each soil sample was plated onto a synthetic medium $(12 \%(w / v)$ $\mathrm{Na}_{2} \mathrm{HPO}_{4}, 0.3 \% \mathrm{KH}_{2} \mathrm{PO}_{4}, 0.1 \%$ D-glucose, $0.05 \% \mathrm{NaCl}$, $0.002 \% \mathrm{CaCl}_{2}, 0.0003 \% \mathrm{MgSO}_{4} \cdot 7 \mathrm{H}_{2} \mathrm{O}$, and $2 \%(w / v)$ agar, $\mathrm{pH}$ 6.2), in which ( \pm )-alliin was added at the concentration of $0.1 \%$ as a sole nitrogen source. After 7 -days incubation at $25^{\circ} \mathrm{C}$, colonies formed were isolated as alliin-utilizing strains, and were independently inoculated onto the agar plates for evaluation of odorous compound production. Six strains were chosen, but cells of these strains were poorly grown in the liquid synthetic medium with the above composition. Therefore, alliinase activity was assayed with cells cultivated in the nutrient medium as described in the following section. A strain with the highest activity was chosen and designated strain FERM P-19486, which has been deposited in the National Institute of Advanced Industrial Science and Technology (Tsukuba, Japan).

\section{Identification of isolated strain FERM P-19486}

Strain FERM P-19486 was identified on the basis of $16 \mathrm{~S}$ rDNA sequence in addition to the morphological and physiological properties examined according to the guideline of Casida (1982). The genomic DNA was extracted with the DNeasy Tissue Kit (QIAGEN, Valencia, CA). PCR amplification of the 16S rDNA and its sequence analysis were performed with the MicroSeq Full Gene 16S rDNA kit (Applied Biosystems, Foster City, CA).

\section{Enzyme assay}

The standard alliinase assay mixture contained $40 \mathrm{mM}$ ( \pm )-alliin, $20 \mu \mathrm{M}$ pyridoxal 5'-phosphate (PLP), $50 \mathrm{mM}$ sodium phosphate ( $\mathrm{pH} 7.0)$, and enzyme in a total volume of $1.0 \mathrm{ml}$. Alliinase activity was determined by colorimetrically measuring pyruvic acid produced in the reaction as described by Durbin and Uchytil (1971). One unit of the enzyme activity was defined as the enzyme amount that catalyzed the formation of $1 \mu$ mole of pyruvic acid per min at $30^{\circ} \mathrm{C}$. Protein concentration was measured according to the method of Bradford using bovine serum albumin as a standard (Bradford, 1976).

\section{Measurement of alliin, allicin, and ammonia}

In the reaction with $( \pm)$-alliin, the remaining concentrations of $(+)$-alliin and (-)-alliin were measured by HPLC using a reverse-phase $\mathrm{C}_{18}$ column (YMC-Pack ODSAM, YMC Co., Kyoto, Japan) at $220 \mathrm{~nm}$. In this HPLC analysis, (+)-alliin and (-)-alliin could be separated by isocratic elution, which was done with $10 \mathrm{mM}$ sodium phosphate buffer ( $\mathrm{pH} 7.5$ ) containing $5 \mathrm{mM}$ tetra $n$-butylammonium dihydrogenphosphate at a flow rate of $1.0 \mathrm{ml}$ per min. Allicin was also measured by HPLC using the same column except that it was isocratically 
eluted with a mixture of acetonitrile, $\mathrm{H}_{2} \mathrm{O}$, and tetrahydrofuran at a ratio of 30: 67: $3(v / v)$ and detected at $240 \mathrm{~nm}$. Ammonia were colorimetrically measured as described by Mazelis and Creveling (1975).

\section{Enzyme purification}

\section{(i) Preparation of cell free extract}

Strain FERM P-19486 was routinely grown in the nutrient medium, which consisted of $3 \%(w / v)$ bouillon (Nissui Co., Tokyo, Japan), at $30^{\circ} \mathrm{C}$ for $3 \mathrm{~d}$ with vigorous shaking. Cells from 1,000 ml culture were collected by centrifugation at 7,000 $\times g$ for $10 \mathrm{~min}$, washed, and suspended with $0.02 \mathrm{M}$ sodium phosphate buffer, $\mathrm{pH} 7.0$ (buffer A). Cells were then disrupted by ultrasonic treatment at $0^{\circ} \mathrm{C}$ using a Branson Sonifier 250, and the supernatant obtained after removing cell debris was used as a crude enzyme.

\section{(ii) DEAE-cellulose column chromatography}

The supernatant was put on a DEAE-cellulose column $(3.0 \times 14.0 \mathrm{~cm})$ equilibrated with buffer A. After washing the column with the same buffer, the enzyme was eluted with buffer A containing $0.05 \mathrm{M} \mathrm{NaCl}$.

\section{(iii) Phenyl-sepharose column chromatography}

After addition of $\mathrm{NaCl}$ to the active fraction at $1.5 \mathrm{M}$, it was then put on a phenyl-sepharose (Amersham Pharmacia Biotech, Uppsala, Sweden) column $(1.5 \times 3.0 \mathrm{~cm})$ equilibrated with buffer A containing $1.5 \mathrm{M} \mathrm{NaCl}$. After washing the column with the same buffer, the enzyme was eluted with buffer $A$. The active fractions were combined and dialyzed against buffer A.

\section{(iv) Aminohexyl-sepharose column chromatography}

The enzyme was put on an aminohexyl-sepharose (Sigma-Aldrich, St. Louis, MO) column $(1.5 \times 6.0 \mathrm{~cm})$ equilibrated with buffer A. After the column was washed with the same buffer, the enzyme was eluted with a linear gradient of buffer A to buffer A containing $0.3 \mathrm{M}$ $\mathrm{NaCl}$. The volume of each fraction was $5 \mathrm{ml}$. The active fractions were combined and concentrated to about $500 \mu \mathrm{l}$ with an Ultrafree-MC (30,000 NMWL, Millipore, Bedford, MA).

\section{(v) Mono $Q$ column chromatography}

The enzyme solution was then applied to a Mono Q (Pharmacia, Uppsala, Sweden) column $(5.0 \times 50 \mathrm{~mm})$ equilibrated with buffer A. After the column was washed with the same buffer, the enzyme was eluted with a linear gradient of buffer A to buffer A containing $0.2 \mathrm{M}$ $\mathrm{NaCl}$. The flow rate was $1 \mathrm{ml} / \mathrm{min}$. The active fractions were combined and concentrated to about $50 \mu \mathrm{l}$ with an Ultrafree-MC (30,000 NMWL).

\section{(vi) Gel filtration}

The enzyme was then applied to a TSK-GEL (TOSOH, Tokyo, Japan) column $(7.8 \times 300 \mathrm{~mm})$ equilibrated with buffer $\mathrm{A}$. The flow rate was $1 \mathrm{ml} / \mathrm{min}$. The active fractions were combined and used as the purified enzyme.

\section{Electrophoresis}

The purity of the enzyme was examined by native-polyacrylamide gel electrophoresis (PAGE) using $8 \%$ polyacrylamide gel at a constant current of $20 \mathrm{~mA}$ per gel at $4^{\circ} \mathrm{C}$. For detection of alliinase activity, gel slices were cut from another lane with the same sample, and each gel slice was directly incubated in $100 \mu \mathrm{l}$ of the standard alliinae assay mixture at $30^{\circ} \mathrm{C}$ for $30 \mathrm{~min}$. Allicin produced in the mixture was measured by HPLC. Sodium dodecyl sulfate (SDS)-PAGE was carried out using 10\% $(w / v)$ polyacrylamide gel at a constant current of $20 \mathrm{~mA}$ per gel, in which broad-range molecular mass standards (Bio-Rad Laboratories, Tokyo, Japan) were simultaneously run. Proteins were detected by silver staining.

\section{Molecular mass determination}

The molecular mass of the native enzyme was estimated by gel filtration using a TSK-GEL column. The operating condition was already described above. The column was calibrated by using the standard proteins: thyroglobulin $(669 \mathrm{kDa})$, ferritin $(440 \mathrm{kDa})$, catalase $(232 \mathrm{kDa})$, lactate dehydrogenase $(140 \mathrm{kDa})$, and bovine serum albumin $(66 \mathrm{kDa})$. The molecular mass of the enzyme under denaturing conditions was determined by SDSPAGE.

\section{Measurement of cell viability in medium containing ( \pm )-alliin and P-19486 alliinase}

S. cerevisiae W303-1A cells were grown at $30^{\circ} \mathrm{C}$ for $16 \mathrm{~h}$ with vigorous shaking in YPD medium containing $1 \%$ $(w / v)$ yeast extract, $2 \%(w / v)$ peptone, and 2\% $(w / v)$ $\mathrm{D}$-glucose. An overnight-grown culture was diluted with freshly prepared YPD medium to obtain an initial cell density of $10^{7}$ cells $/ \mathrm{ml}$, in which PLP was supplemented at $20 \mu \mathrm{M}$. Incubation was then started at $30^{\circ} \mathrm{C}$ with the addition of various concentrations of $( \pm)$-alliin and FERM P-19486 alliinase. Aliquots of the cell suspension were withdrawn, diluted, and spread onto YPD-agar plates to measure the viable cell number as colonyforming units after a $24-\mathrm{h}$ incubation at $30^{\circ} \mathrm{C}$.

\section{Chemicals}

$( \pm)$-Alliin, (+)-alliin, and allicin were products of LKT Laboratories, Inc (St. Paul, MN). S-Methyl-L-cysteine and $S$-ethyl-L-cysteine were obtained from ICN Pharmaceuticals, Inc (Costa Mesa, CA). S-Methyl-L-cysteine sulfoxide was from Research Organics, Inc (Cleveland, $\mathrm{OH})$.

\section{Results}

\section{Identification of strain FERM P-19486}

As summarized in Table 1, strain FERM P-19486 is a rod-shaped bacterium with a size of $1.2-2.0 \mu \mathrm{m}$ in length and 0.6-0.7 $\mu \mathrm{m}$ in diameter. The bacterium was 
Table 1 Tanxonomical features of strain FERM P-19486

\begin{tabular}{lc}
\hline Shape & Short rods \\
& $(\mathbf{0 . 6}-\mathbf{0 . 7} \times \mathbf{1 . 2}-\mathbf{2 . 0} \boldsymbol{\mu \mathrm { m } )})$ \\
\hline Motility & + \\
Spore & - \\
Gram stain & - \\
Anearobic growth & - \\
Cytochrome oxidase & + \\
Catalase & + \\
OF test & Acid \\
Nitrate reduction & + \\
Urease & + \\
Gelatin liquefaction & - \\
Starch hydrolysis & - \\
\hline
\end{tabular}

Gram-negative, aerobic, non-spore forming, motile, catalase-positive, and cytochrome oxidase-positive. Gelatin and starch were not utilized. In addition to these morphological and physiological properties, the carbohydrate and amino acid assimilation patterns were identical to those described for a type culture of Ensifer adhaerens except for the growth defect of the isolated strain FERM P-19486 at $37^{\circ} \mathrm{C}$ (Casida 1982; Sawada et al. 2003). $16 \mathrm{~S}$ rDNA sequence of strain FERM P-19486 showed 100\% homology to that of E. adhaerens ATCC 33499 (Rogel et al. 2001), which is sited at GenBank (AF191738, http://www.ncbi.nlm.nih.gov/nuccore/6180038), agreeing with the identification of the strain to be E. adhaerens.

\section{Purification of P-19486 alliinase}

The enzyme was purified 300-fold from the crude extract with the overall yield of $1.2 \%$ (Table 2). The purified preparation was shown to be homogenous by native-PAGE, in which allicin produced from alliin was detected with the corresponding protein band (Figure 2). The specific activity of P-19486 alliinase was slightly reduced at the final step of purification, suggesting the loss of stability in association with the purity increase. The addition of PLP to buffer A used during chromatography was ineffective in preventing the loss of activity. Unlike the case with heat denaturation, however, the specific activity remained at a constant level for at least 1 week at $-20^{\circ} \mathrm{C}$ or even at $4^{\circ} \mathrm{C}$. It remains to be solved whether the enzyme requires a certain factor for the maximum activity.

\section{Physicochemical properties}

P-19486 alliinase had a molecular mass of $96 \mathrm{kDa}$, and consisted of two subunits identical in molecular mass (48 kDa), as judged by the analyses based on gel filtration and SDSPAGE. P-19486 alliinase was most active at $60^{\circ} \mathrm{C}$, though the enzyme was unstable above $20^{\circ} \mathrm{C}$, as seen from the loss of activity to $42 \%$ of the maximum value (Figure $3 \mathrm{a}$ ). The enzyme was stable in the alkaline $\mathrm{pH}$ range between 7.0 and 9.0, in which the maximum activity was detected at around pH 8.0 (Figure $3 \mathrm{~b}$ ). This suggested that the substrate alliin contributed to the maintenance of enzyme stability during incubation at $60^{\circ} \mathrm{C}$. Alliinases so far reported are typical PLP-dependent enzyme (Tobkin and Mazelis 1979; Kuettner et al. 2002a, b). The activity of P-19486 alliinase in the absence of PLP was only $14.3 \%$ of that detected in the presence of $20 \mu \mathrm{M}$ PLP, suggesting that PLP is also a cofactor of this enzyme.

\section{Selectivity toward diastereomer of alliin}

Two diastereomers, (+)-S-allyl-L-cysteine sulfoxide and (-)-S-allyl-L-cysteine sulfoxide, exist in the molecular structure of alliin because of the asymmetry of the sulfoxide group. As summarized in Table 3, P-19486 alliinase exhibited the lyase activity on $( \pm)$-alliin more effectively than (+)-alliin, reflecting its selectivity toward (-)-alliin. The enzyme was also active on $( \pm)-S$-methyl-L-cysteine sulfoxide with a higher $V_{\max }$ value than $(+)$-alliin. This should also reflect its selective action on (-)-isomer of the substrate. The $K \mathrm{~m}$ value of P-19486 alliinase for ( \pm )-alliin was $2.3 \mathrm{mM}$, and was apparently lower than that for $(+)$-alliin $(5.7 \mathrm{mM})$, suggesting that the $K \mathrm{~m}$ value for (-)-alliin might be around $1 \mathrm{mM}$ or less. We therefore examined whether P-19486 alliinase can selectively react with (-)-alliin under the condition where the concentration of each diastereomer was adjusted to the level less than the possible $K \mathrm{~m}$ value for (-)-alliin. As shown in Figure 4, P-19486 alliinase could selectively decompose $(-)$-alliin, whereas the level of (+)-alliin was kept unchanged at least during 30-min incubation.

Table 2 Purification of alliinase from E. adhaerens FERM P-19486

\begin{tabular}{lrrrrr}
\hline Purification step & $\begin{array}{r}\text { Protein } \\
\text { (mg) }\end{array}$ & $\begin{array}{r}\text { Total activity } \\
\text { (units) }\end{array}$ & $\begin{array}{r}\text { Sp. Act } \\
\text { (units/mg) }\end{array}$ & $\begin{array}{r}\text { Yield } \\
\text { (\%) }\end{array}$ & $\begin{array}{r}\text { Purification } \\
\text { (fold) }\end{array}$ \\
\hline Crude extract & 209.81 & 73.0 & 0.3 & 100 & 1 \\
DEAE-cellulose & 9.60 & 30.0 & 3.1 & 41.1 & 10 \\
Phenyl-sepharose & 1.94 & 22.4 & 11.5 & 30.7 & 38 \\
Aminohexyl-sepharose & 0.29 & 7.5 & 25.9 & 10.3 & 56 \\
Mono Q & 0.04 & 4.1 & 102.5 & 3.6 & 3.2 \\
TSK-GEL & 0.01 & 0.9 & 90.0 & & 300 \\
\hline
\end{tabular}




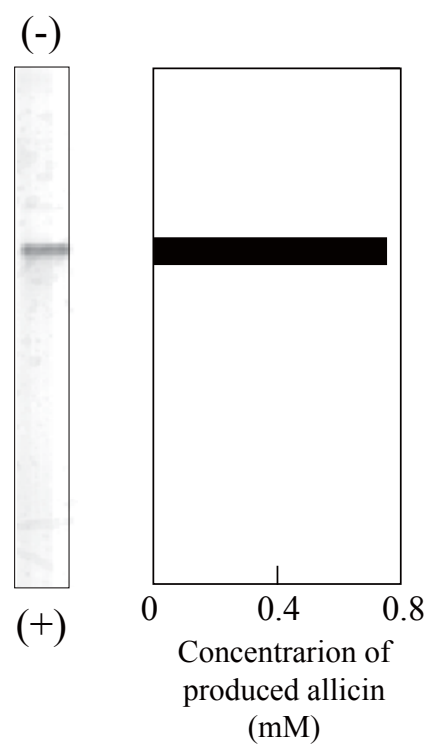

Figure 2 PAGE of purified P-19486 alliinase (left) and the detection of the enzyme activity on the gel (right). The purified enzyme (100 ng) was applied to each lane and was run at a constant current of $20 \mathrm{~mA}$ at $0^{\circ} \mathrm{C}$. After electrophoresis, one lane was used for protein staining (left) and the other one was for alliinase assay. Closed bar of right hand side indicates the location of allicin production on the gel.

Generation of a fungicidal activity in medium containing (士)-alliin and P-19486 alliinase

$( \pm)$-Alliin itself weakly inhibited the growth of S. cerevisiae cells at $40 \mathrm{mM}$ (data not shown). In medium containing $1 \mathrm{mM}( \pm)$-alliin, however, the yeast cell growth was absolutely inhibited in the presence of P-19486
Table 3 Substrate specificity of alliinase from E. adhaerens FERM P-19486

\begin{tabular}{|c|c|c|c|}
\hline \multirow[t]{2}{*}{ Substrate } & \multicolumn{3}{|c|}{ Kinetic constants } \\
\hline & $\begin{array}{c}V_{\max }{ }^{a} \\
\text { (units/mg) }\end{array}$ & $\begin{array}{c}\mathrm{Km} \\
(\mathrm{mM})\end{array}$ & $V_{\text {max }} / K m$ \\
\hline$( \pm)$-Alliin & 90.0 & 2.3 & 39.1 \\
\hline$(+)$-Alliin & 18.5 & 5.7 & 3.2 \\
\hline S-Allyl-L-cysteine & 66.1 & 10.6 & 6.2 \\
\hline S-Methyl-L-cysteine & 15.3 & $-b$ & - \\
\hline ( \pm )-S-Methyl-L-cysteine sulfoxide & 53.6 & - & - \\
\hline S-Ethyl-L-cysteine & 29.7 & - & - \\
\hline L-Cysteine & 1.6 & - & - \\
\hline
\end{tabular}

a The $V_{\max }$ value was obtained by the rate of pyruvic acid production in the standard reaction mixture containing each substrate at $40 \mathrm{mM}$.

${ }^{\mathrm{b}}$ Not tested.

allinase at 0.64 unit per $\mathrm{ml}$ (Figure $5 \mathrm{a}$ ). At the same dose, the enzyme could generate a significant lethal damage in medium containing $( \pm)$-alliin at $2 \mathrm{mM}$ (Figure $5 \mathrm{~b}$ ). Under the condition, the rate of allicin production should be dependent on the substrate concentration, as deduced from the $K \mathrm{~m}$ value of the enzyme $(2.3 \mathrm{mM})$. As expected, the enzyme was effective for causing cell death at a lower dose $(0.32$ unit per $\mathrm{ml})$ in medium where the concentration of $( \pm)$-alliin was increased up to $4 \mathrm{mM}$ (Figure $5 \mathrm{c}$ ). These results indicate the possibility of applying P-19486 alliinase for on-site generation of allicin-dependent fungicidal activity.

\section{Discussion}

The alliinase-producing bacterium FERM P-19486 was identified as E. adhaerens. E. adhaerens constitutes a
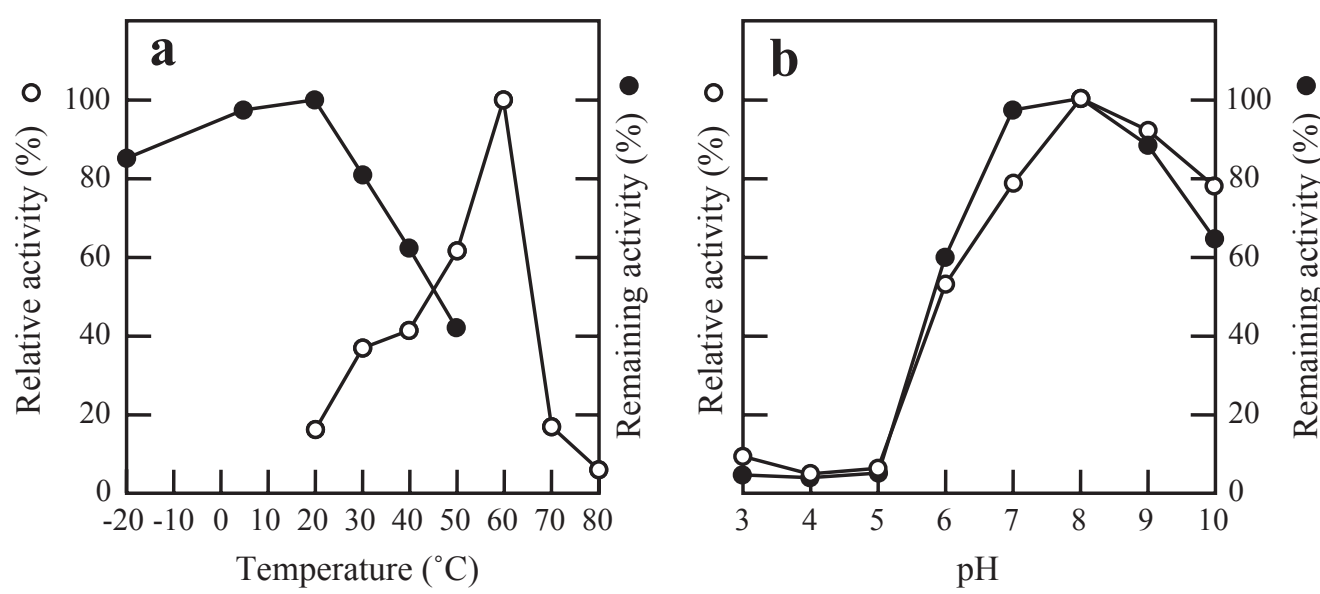

Figure 3 Effects of temperature (a) and $\mathbf{p H ~ ( b ) ~ o n ~} \mathbf{P}-\mathbf{1 9 4 8 6}$ alliinase. In (a), the optimum temperature (open circle) was determined by incubating the enzyme under the standard assay condition at each temperature. In the assay of thermal stability (closed circle), the enzyme activity was measured by the addition of $( \pm$ )-alliin to the standard assay mixture, in which the enzyme had been preincubated at each temperature for $30 \mathrm{~min}$. In (b), the optimum pH (open circle) was determined by incubating the enzyme under the standard assay condition where $\mathrm{pH}$ of the mixture was adjusted as indicated. In the assay of pH stability (closed circle), the enzyme activity was measured by the addition of $\left( \pm\right.$ )-alliin to the standard assay mixture, in which the enzyme had been preincubated at $4^{\circ} \mathrm{C}$ and at each $\mathrm{pH}$ for $30 \mathrm{~min}$. 


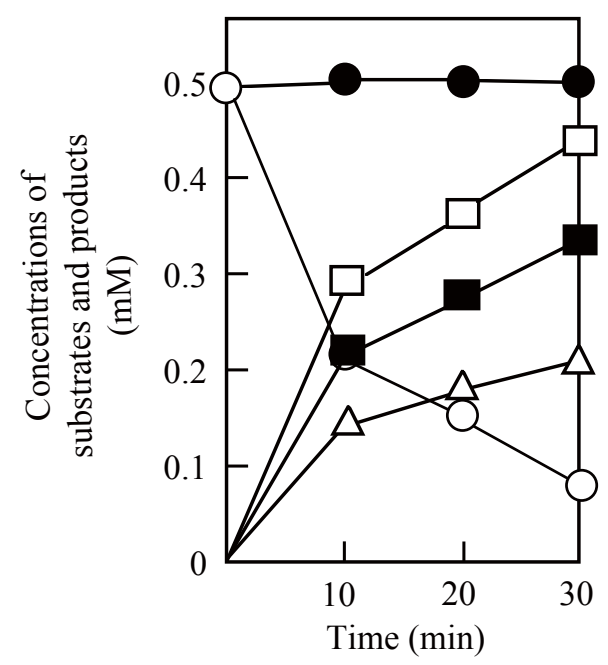

Figure 4 Conversion of $( \pm$ )-alliin to pyruvic acid, ammonia, and allicin by $\mathrm{P}-19486$ alliinase. The reaction mixture containing $1 \mathrm{mM}$ ( \pm )-alliin, $20 \mu \mathrm{M}$ PLP, and P-19486 alliinase (0.1 unit) in $1.0 \mathrm{ml}$ of 50 $\mathrm{mM}$ sodium phosphate buffer $(\mathrm{pH} 7.0)$ was incubated at $30^{\circ} \mathrm{C}$. Portions were withdrawn for the measurement of pyruvic acid (open square) and ammonia (closed square) by the colorimetric methods. The concentrations of (+)-alliin (closed circle), (-)-alliin (open circle), and allicin (open triangle) were measured by the HPLC-analyses.

group of non-nodulating bacteria that do not harbor nifH gene, but the genus Ensifer, comprising the former Sinorhizobium species and Ensifer adhaerens, contain bacteria capable of nitrogen fixation in symbiosis with leguminous plants (Martens et al. 2008).

Plant alliinases so far reported are homodimeric glycoproteins consisting of two identical subunits (Schwimmer and Mazelis 1963; Mazelis and Crews 1968; Tobkin and Mazelis 1979; Nock and Mazelis
1986; Landshuter et al. 1994; Lohmüller et al. 1994; Rabinkov et al. 1994; Manabe et al. 1998; Kuettner et al. 2002a, b). Microbial alliinase has been only roughly purified from a fungus $P$. corymbiferum so that general properties of the fungal enzyme are mostly kept unknown (Durbin and Uchytil 1971). P-19486 alliinase consisted of 2 homologous subunits and this homodimeric subunit composition is quite similar to those of the enzymes from garlic and onion. PLP is a cofactor essential for the C-S lyase activity of alliinase so far reported (Tobkin and Mazelis 1979; Kuettner et al. 2002a, b; Shimon et al. 2007). Although each subunit of alliinase contains one tightly bound PLP, its exogenous addition enhances the enzyme activity as the purification proceeds (Schwimmer and Mazelis 1963; Mazelis and Crews 1968). Such an enhancement effect of PLP on the enzyme activity also suggested the involvement of bound PLP in the C-S lyase activity of P-19486 alliinase.

There exist two diastereomers, (+)-S-allyl-L-cysteine sulfoxide and (-)-S-allyl-L-cysteine sulfoxide, in the molecular structure of alliin because of the asymmetry of the sulfoxide group. These diastereomeric forms may not equally serve as a substrate for alliinase, if the stereochemically active center is involved in the enzyme reaction. Garlic alliinase more rapidly hydrolyzes (+)-alliin, a naturally occurring substrate for the enzymatic synthesis of allicin, than (-)-alliin (Stoll and Seeback 1951; Lancaster and Collin 1981; Kuettner et al. 2002b; Shimon et al. 2007). P-19486 alliinase seems to have a distinct amino acid sequence around the active site region for its strong contact with the sulfoxide group of (-)-alliin.

Alliinase shows a strict specificity toward alliin except that onion root isoforms, which are different in glycosylation, exhibit an additional activity toward L-cystine to
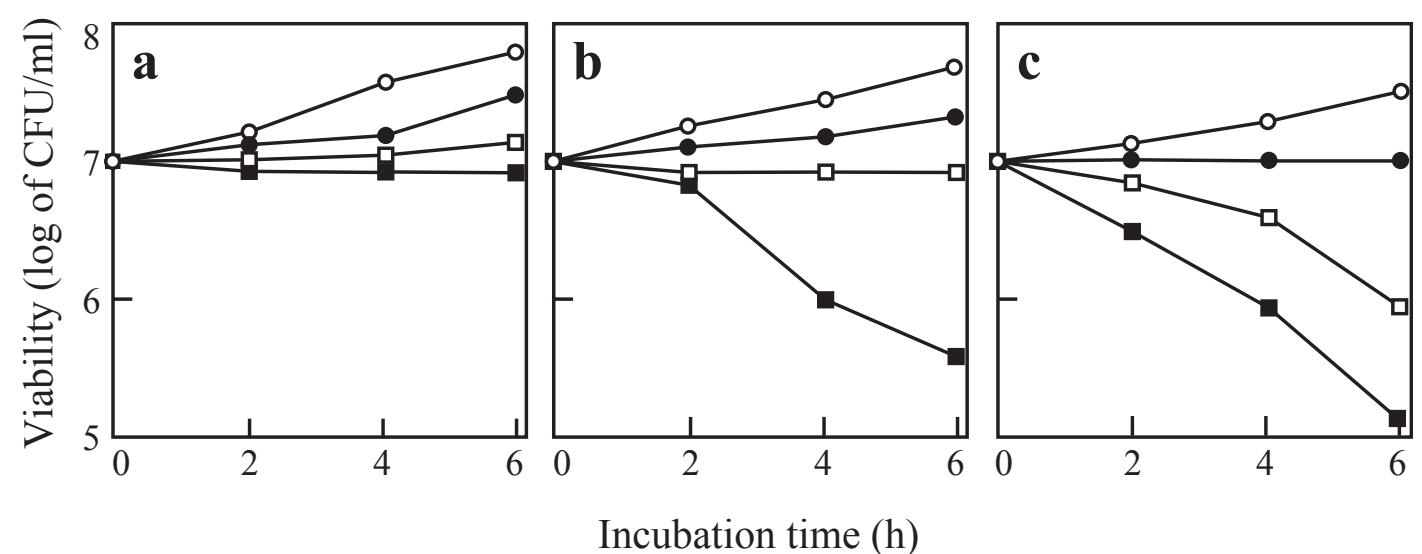

Figure 5 Generation of a fungicidal activity in the presence of $( \pm)$-alliin and P-19486 alliinase. S. cerevisiae cells were incubated in YPD medium containing ( \pm )-alliin at 1 (a), 2 (b), and 4 mM (c), in which P-19486 alliinase wad supplemented at 0.04 (open circle), 0.16 (closed circle), 0.32 (open square), and 0.64 unit per $\mathrm{ml}$ (closed square). Viability was expressed as colony-forming units. 
a limited extent (Lancaster et al. 2000). Therefore, plant alliinase is fundamentally distinguished from $S$-alkyl L-cysteine lyase (EC 4.4.1.6), which stoichiometrically converts $S$-alkyl L-cysteine to $S$-alkyl mercaptan, pyruvic acid, and ammonia, as illustrated in Figure 1b (Schwimmer and Kjær 1960; Nomura et al. 1963; Mazelis and Creveling 1975). S-Alkylcysteine lyase from the bacterium Pseudomonas cruciviae similarly catalyzed the lyase action on $( \pm)-S$-alkyl-L-cysteine sulfoxide including $( \pm)$-alliin though the additional condensation reaction for allicin synthesis is not known for this bacterial enzyme (Nomura et al. 1963). In the sense, P-19486 alliinase is a novel enzyme that can alternatively exhibit the allicin synthetic activity on (-)-S-allyl-L-cysteine sulfoxide, (-)-alliin, and the C-S lyase activity on $S$-alkyl-Lcysteine (Table 3$)$.

Allicin exhibits antifungal activity against various fungi including S. cerevisiae and the pathogenic yeast Candia albicans (Ankri and Mirelman 1999). In addition, allicin can enhance the fungicidal activity of amphotericin B, the most representative antifungal antibiotic, against these yeast strains (Ogita et al. 2006; Borjihan et al. 2009). A chemically synthesized allicin was used in these studies, whereas its enzymatic synthesis or even on-site production has been examined with the aid of garlic alliinase (Miron et al. 2003; Shadkchan et al. 2004; Fry et al. 2005; Slusarenko et al. 2008). It was doubtful whether P-19486 alliinase can be industrially or medically applied for allicin production because of its low thermal stability. However, this bacterial enzyme could effectively catalyze the corresponding allicin synthetic reaction using $( \pm)$-alliin at the concentration lower than the $K \mathrm{~m}$ value (see Table 3 and Figure 4). In agreement with this fact, P-19486 alliinase could successfully generate a fungicidal activity using $( \pm)$-alliin as a precursor, which is easily synthesized by chemical oxidation of $S$-allyl-L-cysteine. The bacterial enzyme may be more beneficial when used in combination with garlic enzyme with respect to absolute conversion of $( \pm)$-alliin to allicin.

\section{Acknowledgements}

This study was supported in part by a Grant-in-Aid for Scientific Research (C) (No. 20580083) from the Ministry of Education, Culture, Sports, Science and Technology of Japan. The authors are grateful to Gong qinqin for her technical assistance to this work.

\section{Author details}

'Department of Biology and Geosciences, Graduate School of Science, Osaka City University, 3-3-138 Sugimoto, Sumiyoshi-ku, Osaka 558-8585, Japan. ${ }^{2}$ Research Center for Urban Health and Sports, Osaka City University, 3-3-138 Sugimoto, Sumiyoshi-ku, Osaka 558-8585, Japan.

\section{Authors' contributions}

MY and HT participated in all experiments except an assay of antifungal activity. $\mathrm{HB}$ carried out an assay of antifungal activity. AO, KF, and $\Pi$ participated in design and coordination of this study. All authors read and approved the final manuscript.

\section{Competing interests}

The authors declare that they have no competing interests.

Received: 12 January 2010 Accepted: 28 March 2011

Published: 28 March 2011

\section{References}

Agarwal KC (1996) Therapeutic actions of garlic constituents. Med Res Rev 16:111-124

Ankri S, Mirelman D (1999) Antimicrobial properties of allicin from garlic. Microbes Infect 1:125-129

Block E (1985) The chemistry of garlic and onions. Sci Am 252:114-119

Borjihan H, Ogita A, Fujita K, Hirasawa E, Tanaka T (2009) The vacuole-targeting fungicidal activity of amphotericin B against the pathogenic fungus Candida albicans and its enhancement by allicin. J Antibiot 62:691-697

Bradford MM (1976) A rapid and sensitive method for the quantitation of microgram quantities of protein utilizing the principle of protein-dye binding. Anal Biochem 72:248-254

Casida LE Jr (1982) Ensifer adhaerens gen. nov., sp. nov.: a bacterial predator of bacteria in soil. Int J Syst Bacteriol 32:339-345

Durbin RD, Uchytil TF (1971) Purification and properties of alliin lyase from the fungus Penicillium corymbiferum. Biochim Biophys Acta 235:518-520

Fry FH, Okarter N, Baynton-Smith C, Kershaw MJ, Talbot NJ, Jacob C (2005) Use of a substrate/alliinase combination to generate antifungal activity in situ. J Agric Food Chem 53:574-580

Jones MG, Hughes J, Tregova A, Milne J, Tomestt AB, Collin HA (2004) Biosynthesis of the flavor precursors of onion and garlic. J Exp Botany 55:1903-1918

Kuettner EB, Hilgenfeld R, Weiss MS (2002a) Purification, characterization, and crystallization of alliinase from garlic. Arch Biochem Biophys 402:192-200

Kuettner EB, Hilgenfeld R, Weiss MS (2002b) The active principle of garlic at atomic resolution. J Biol Chem 277:46402-46407

Lancaster JE, Collin HA (1981) Presence of alliinase in isolated vacuoles and of alkyl cysteine sulphoxides in the cytoplasm of bulbs of onion (Allium cepa). Plant Sci Lett 22:169-176

Lancaster JE, Shaw ML, Joyce MD, McCallum JA, McManus MT (2000) A novel alliinase from onion roots. Biochemical characterization and CDNA cloning. Plant Physiol 122:1269-1279

Landshuter J, Lohmüller EM, Knobloch K (1994) Purification and characterization of a C-S-lyase from ramson, the wild garlic Allium ursinum. Planta Med 60:343-347

Lohmüller EM, Landshuter J, Knobloch K (1994) On the isolation and characterization of a C-S-lyase preparation from leek, Allium porrum. Planta Med 60:337-342

Manabe T, Hasumi A, Sugiyama M, Yamazaki M, Saito K (1998) Alliinase [S-alk(en) yl-L-cysteine sulfoxide lyase] from Allium tuberosum (Chinese chive) purification, localization, CDNA cloning and heterologous functional expression. Eur J Biochem 257:21-30

Martens M, Dawyndt P, Coopman R, Gillis M, De Vos P, Willems A (2008) Advantages of multilocus sequence analysis for taxonomic studies: a case study using 10 housekeeping genes in the genus Ensifer (including former Sinorhizobium). Int J Syst Evol Microbiol 58:200-214

Mazekis M, Creveling RK (1975) Purification and properties of S-alkyl-L-cysteine lyase from seedlings of Acacia farnesiana Willd. Biochem J 147:485-491

Mazelis M, Crews L (1968) Purification of the alliin lyase of garlic, Allium sativum L. Biochem J 108:725-730

Miron T, Mironchik M, Mirelman D, Wilchek M, Rabinkov A (2003) Inhibition of tumor growth by a novel approach: in situ allicin generation using targeted alliinase delivery. Mol Cancer Ther 2:1295-1301

Murakami F (1960) Studies on the nutritional value of Allium plants: (XXXVII) Decomposition of alliin homologues by acetone-powdered enzyme preparation of Bacillus subtilis. Vitamins 20:131-135

Nock LP, Mazelis M (1986) The C-S lyases of higher plants: preparation and properties of homogeneous alliin lyase from garlic (Allium sativum). Arch Biochem Biophys 249:27-33

Nomura J, Nishizuka Y, Hayaishi O (1963) S-Alkylcysteinase: Enzymatic cleavage of S-methyl-L-cysteine and its sulfoxide. J Biol Chem 238:1441-1446 
Ogita A, Fujita K, Taniguchi M, Tanaka T (2006) Enhancement of the fungicidal activity of amphotericin B by allicin, an allyl-sulfur compound from garlic, against the yeast Saccharomyces cerevisiae as a model system. Planta Med 72:1247-1250

Rabinkov A, Zhu XZ, Grafi G, Galili G, Mirelman D (1994) Alliin lyase (alliinase) from garlic (Allium sativum). Biochemical characterization and CDNA cloning Appl Biochem Biotchnol 48:149-171

Rogel MA, Hernández-Lucas I, Kuykendall LD, Balkwill DL, Martinez-Romero E (2001) Nitrogen-fixing nodules with Ensifer adhaerens harboring Rhizobium tropici symbiotic plasmids. Appl Environ Microbiol 67:3264-3268

Sawada H, Kuykendall LD, Young JM (2003) Changing concepts in the systematics of bacterial nitrogen-fixing legume symbionts. J Gen Appl Microbiol 49:155-179

Schwimmer S, Kjær A (1960) Purification and specificity of the C-S-lyase of Albizzia lophanta. Biochim Biophys Acta 42:316-324

Schwimmer S, Mazelis M (1963) Characterization of alliinase of Allium cepa (onion). Arch Biochem Biophys 100:66-73

Shadkchan Y, Shemesh E, Mirelman D, Miron T, Rabinkov A, Wilchek M, Osherov N (2004) Efficacy of allicin, the reactive molecule of garlic, in inhibiting Aspergillus spp. in vitro, and in a murine model of disseminated aspergillosis. J Antimicrob Chemother 53:832-836

Shimon JWL, Rabinkov A, Shin I, Miron T, Mirelman D, Wilchek M, Frolow F (2007) Two structures of alliinase from Allium sativum L.: Apo form and ternary complex with aminoacrylate reaction intermediate covalently bound to the PLP cofactor. J Mol Biol 366:611-625

Siegel G, Walter A, Engel S, Walper A, Michel F (1999) Pleiotropic effects of garlic. Wien Med Wochenschr 149:217-224

Slusarenko AJ, Patel A, Portz D (2008) Control of plant disease by natural products: allicin from garlic as a case study. Eur J Plant Pathol 121:313-322

Stoll A, Seeback E (1951) Chemical investigation on alliin, the specific principle of garlic. Adv Enzymol 11:337-400

Tobkin HE Jr, Mazelis M (1979) Alliin lyase: preparation and characterization of the homogeneous enzyme from onion bulbs. Arch Biochem Biophys 193:150-157

Tsai Y, Cole LL, Davis LE, Lockwood SJ, Simmons V, Wild GC (1985) Antiviral properties of garlic: in vitro effects on influenza $B$, herpes simplex and coxsackie viruses. Planta Med 51:460-461

doi:10.1186/2191-0855-1-2

Cite this article as: Yutani et al:: Alliinase from Ensifer adhaerens and Its Use for Generation of Fungicidal Activity. AMB Express 2011 1:2.

\section{Submit your manuscript to a SpringerOpen ${ }^{\odot}$ journal and benefit from:}

- Convenient online submission

- Rigorous peer review

- Immediate publication on acceptance

- Open access: articles freely available online

- High visibility within the field

- Retaining the copyright to your article

Submit your next manuscript at $\gg$ springeropen.com 